\title{
Immunization guidance products: Different levels of detail for different uses
}

\author{
Desai $\mathrm{S}^{1 *}$, Tunis $\mathrm{M}^{1}$, Stirling $\mathrm{R}^{1}$, Jensen $\mathrm{C}^{1}$, Ismail $\mathrm{S}^{1}$, Baclic $\mathrm{O}^{1}$, Lerch $\mathrm{R}^{1}$
}

\begin{abstract}
The National Advisory Committee on Immunization (NACl) provides expert and evidence-based advice to the Public Health Agency of Canada (PHAC) on the use of human vaccines in Canada. This advice is presented in a variety of publications for different uses. A recent survey identified some confusion regarding the various $\mathrm{NACl}$ publication products. The objective of this article is to identify the level of detail and appropriate uses of the different $\mathrm{NACl}$ products.

$\mathrm{NACl}$ statements provide a synthesis of current evidence and expert opinion on new vaccines or new indications for vaccines to inform immunization practices, policies and programs. $\mathrm{NACl}$ literature reviews inform new $\mathrm{NACl}$ statements and are published after the statement to inform readers about current literature on a specific immunization topic. The Canadian Immunization Guide $(\mathrm{CIG})$ is a practice-oriented guide that synthesizes all the NACl statements and is updated regularly. NACl statement summaries are published in the Canada Communicable Disease Report (CCDR) and provide a high level overview of these statements shortly after they are published. These products provide a variety of options for users to choose how in-depth they wish to explore the evidence base and process for producing recommendations for immunization in Canada.
\end{abstract}

\section{Affiliation}

${ }^{1}$ Centre for Immunization and Respiratory Infectious Diseases, Public Health Agency of Canada, Ottawa, ON

*Correspondence: naci-ccni@ phac-aspc.gc.ca

Suggested citation: Desai S, Tunis M, Stirling R, Jensen C, Ismail S, Baclic O, Lerch R. Immunization guidance products: Different levels of detail for different uses. Can Comm Dis Rep. 2016;42(12):252-5.

https://doi.org/10.14745/ccdr.v42i12a03

\section{Introduction}

New vaccines and recommendations on the best use of vaccines are being developed on an ongoing basis. Activities related to immunizations are a shared responsibility among the federal, provincial and territorial governments in Canada. The federal government is responsible for the regulation of vaccines, national vaccine safety monitoring, national disease surveillance and provision of expert led immunization advice. The National Advisory Committee on Immunization (NACl) is supported by the Public Health Agency of Canada (PHAC) and has been providing expert and evidence-based advice to the federal government since 1964.

$\mathrm{NACl}$ makes recommendations on the use of vaccines currently or newly approved for use in humans in Canada, including the identification of groups at risk for vaccine preventable diseases for whom vaccination should be targeted (1). The Committee reports to the Assistant Deputy Minister of Infectious Disease Prevention and Control Branch of the Public Health Agency of Canada and works with staff of the Centre for Immunization and Respiratory Infectious Diseases at PHAC to provide ongoing medical, scientific and public health advice.

As the field of vaccine research and evidence-based decision making has evolved, NACl's processes and methods have also evolved. For example, when developing new statements, $\mathrm{NACl}$ often conducts comprehensive literature reviews to guide the expert advice of the Committee (2).
$\mathrm{NACl}$ does more than issue $\mathrm{NACl}$ statements. A variety of products have been developed to serve the needs of different audiences, including frontline providers, policy staff and decision-makers at different levels of government and researchers. $\mathrm{NACl}$ products include $\mathrm{NACl}$ statements, literature reviews, the Canadian Immunization Guide $(\mathrm{CIG})$ and $\mathrm{NACl}$ summaries in the Canada Communicable Disease Report (CCDR).

A recent survey of $\mathrm{NACl}$ stakeholders identified that some users find it difficult to identify which $\mathrm{NACl}$ product is for whom (unpublished data). The objective of this article is to identify the level of detail and appropriate uses of the different $\mathrm{NACl}$ products.

\section{Detailed products}

\section{$\mathrm{NACl}$ statements}

$\mathrm{NACl}$ statements provide a high level of detail. They are a written record of the evidence that was collated and analysed by the Committee and informed the final recommendations. Statements are written when a new product is introduced, when a new and significant indication is authorized, when new evidence on a vaccine becomes available, or when a new question about the use of a vaccine has been reviewed. For example, $\mathrm{NACl}$ was asked to review the use of Hepatitis $\mathrm{A}$ for pre exposure immunization. Following review of the data, $\mathrm{NACl}$ determined that pre exposure immunization could be safely offered for those six months of age and older (3). Additionally, a statement may be needed if there are significant changes in the 
epidemiology of a particular disease or after a new safety signal is detected. For example, after Canadian researchers and others identified a slightly increased risk of febrile seizures following administration of the combined measles, mumps, rubella and varicella vaccine, $\mathrm{NACl}$ developed new recommendations to address this (4). Statements include details about the methods that were used to retrieve and review primary literature, as well as a detailed look at the studies and grading of the evidence that informed the recommendations of $\mathrm{NACl}(5)$.

The target audience for statements includes those interested in immunization decision making, those designing vaccine programs and other policy-makers. While certainly available to frontline providers and useful to read as a continuing medical education activity, $\mathrm{NACl}$ statements offer more detail than is needed to provide immunizations. The types of questions that can be answered from a statement include: What was the evidence that informed these recommendations? What was the quality of this evidence and what role did expert opinion play?

\section{NACI literature reviews}

When there is a large volume of evidence on a topic, $\mathrm{NACl}$ will often conduct or commission an evidence-based review to synthesize the evidence that will inform their recommendations. Once the research questions have been developed by $\mathrm{NACl}$, literature is collected and appraised according to NACl's published methodology (2). This typically includes a detailed description of the methods used to identify appropriate literature along with an in-depth review and description of that literature. Publishing a literature review separately allows the corresponding statement to be streamlined and concise. These reviews do not provide vaccine recommendations or immunization guidance.

The target audience for these comprehensive reviews is individuals who wish to review all the relevant literature related to a specific question that informed a recommendation by $\mathrm{NACl}$. For example, in 2016 a literature review was published on the topic of high dose seasonal influenza vaccine for adults 65 years and older (6). This review provided the evidence base for the 2016-17 Seasonal Influenza Statement on the use of high dose trivalent influenza vaccine in adults 65 years of age and older (7). Not all questions reviewed by NACl have a formal literature review published; it depends in part on the amount of evidence that must be reviewed. The decision to publish a literature review separately from the statement is made on a case by case basis.

\section{Summative products}

\section{The Canadian Immunization Guide}

The $\mathrm{CIG}$ is the authoritative guide on current $\mathrm{NACl}$ immunization recommendations. It began as a small paperback in 1979 (8) and its scope has expanded over time. In 2012-13, the CIG was transformed into an online tool that is now updated regularly to reflect the current state of vaccine knowledge and summarizes the most up-to-date $\mathrm{NACl}$ recommendations as well as travel vaccine recommendations from the Committee to Advise on Tropical Medicine and Travel (CATMAT). It includes sections on key immunization information, vaccine safety, vaccination of specific populations, active vaccines and passive immunizations.
Each section of the CIG is reviewed at least once every four years. Alternatively, when a new NACl or CATMAT statement is published with recommendations, changes to the content in the relevant CIG chapters are also made to ensure that the CIG contains the most up-to-date immunization guidance from $\mathrm{NACl}$ and CATMAT. These changes are highlighted in the Table of Updates on the CIG website (9) and published annually as a summary in CCDR (10). It is particularly useful when multiple statements have been made on a vaccine. For example, there have been many $\mathrm{NACl}$ statements on HPV vaccines over the past decade as the vaccine products and evidence have evolved. The CIG brings together all the current HPV vaccine recommendations and information into one place (11).

The CIG is written in the form of a quick reference guide for frontline immunization providers in Canada. Although routine vaccine schedules may vary among provinces and territories, the CIG provides definitive advice about special populations, travel vaccines, vaccine administration, storage and handling, co-administration of vaccines, passive immunizing agents and more.

\section{$\mathrm{NACl}$ summaries in the CCDR}

Summaries of $\mathrm{NACl}$ statements are published in the CCDR shortly after a new statement is published. They are directed to front line vaccine providers and identify new recommendations and provide a link to the full statement. For example, see the summary in this issue on the interim $\mathrm{NACl}$ recommendations for pneumococcal vaccine (12).

Information on all these $\mathrm{NACl}$ products is summarized in Table 1.

\section{Table 1: An overview of key features of PHAC} publications on $\mathrm{NACl}$ advice

\begin{tabular}{|c|c|c|}
\hline Product & Features & Details \\
\hline \multirow{4}{*}{$\begin{array}{l}\mathrm{NACl} \\
\text { statements }\end{array}$} & $\begin{array}{l}\text { Designed } \\
\text { for }\end{array}$ & $\begin{array}{l}\text { - Informing provincial/territorial vaccine } \\
\text { program discussions and decisions. } \\
\text { - Providing a synthesis of the evidence } \\
\text { informing recommendations and their } \\
\text { rationale. } \\
\text { - Finding key references to research studies } \\
\text { that vaccine recommendations are based on. }\end{array}$ \\
\hline & $\begin{array}{l}\text { Not } \\
\text { designed } \\
\text { for }\end{array}$ & $\begin{array}{l}\text { - Finding key information quickly (such as } \\
\text { preparation of the vaccine, safety details etc.) } \\
\text { to help make decisions when giving vaccines } \\
\text { to patients. } \\
\text { - Background information about vaccines, } \\
\text { vaccine administration and immunological } \\
\text { concepts. }\end{array}$ \\
\hline & Timelines & $\begin{array}{l}\text { - Statements may be updated if: } \\
\text { - There is a new product/indication, } \\
\text { - There has been a significant change in } \\
\text { epidemiology, } \\
\text { - New evidence on a vaccine becomes } \\
\text { available, } \\
\text { - A new question about the use of a vaccine } \\
\text { needs to be reviewed, } \\
\text { - A new safety question has been identified, } \\
\text { OR } \\
\text { - There is a vaccine supply issue }\end{array}$ \\
\hline & $\begin{array}{l}\text { Where to } \\
\text { find them }\end{array}$ & $\begin{array}{l}\text { National Advisory Committee on Immunization } \\
\text { (NACl) Recommendations, Statements and } \\
\text { Updates (http://www.phac-aspc.gc.ca/naci-ccni/ } \\
\text { index-eng.php) }\end{array}$ \\
\hline
\end{tabular}


Table 1 continued

\begin{tabular}{|c|c|c|}
\hline Product & Features & Details \\
\hline \multirow{4}{*}{$\begin{array}{l}\mathrm{NACl} \text { literature } \\
\text { reviews }\end{array}$} & Designed for & $\begin{array}{l}\text { - Informing readers about all research } \\
\text { on a specific immunization topic } \\
\text { that was used in developing } \\
\text { recommendations. } \\
\text { - Informing provincial/territorial } \\
\text { vaccine program discussions and } \\
\text { decisions. } \\
\text { - Providing a detailed review on a } \\
\text { specific research question related to } \\
\text { vaccine use. }\end{array}$ \\
\hline & $\begin{array}{l}\text { Not } \\
\text { designed for }\end{array}$ & $\begin{array}{l}\text { - Finding recommendations for a } \\
\text { specific vaccine. } \\
\text { - Finding information quickly to } \\
\text { help make decisions when giving } \\
\text { vaccines to patients. } \\
\text { - Finding general background } \\
\text { information about vaccines, vaccine } \\
\text { administration and immunological } \\
\text { concepts. }\end{array}$ \\
\hline & Timelines & $\begin{array}{l}\text { - Not updated. New reviews may be } \\
\text { done to inform new statements. }\end{array}$ \\
\hline & $\begin{array}{l}\text { Where to } \\
\text { find them }\end{array}$ & $\begin{array}{l}\text { National Advisory Committee } \\
\text { on Immunization (NACI) } \\
\text { Recommendations, Statements and } \\
\text { Updates } \\
\text { (http://www.phac-aspc.gc.ca/naci- } \\
\text { ccni/index-eng.php) }\end{array}$ \\
\hline \multirow{4}{*}{$\begin{array}{l}\text { Canadian } \\
\text { Immunization } \\
\text { Guide }\end{array}$} & Designed for & $\begin{array}{l}\text { - Finding key up-to-date information } \\
\text { on immunization recommendations } \\
\text { for specific vaccine preventable } \\
\text { diseases to help make decisions } \\
\text { when advising individuals on } \\
\text { vaccinations. } \\
\text { - Background information about } \\
\text { immunology, immunization } \\
\text { practices and principles and vaccine } \\
\text { administration. }\end{array}$ \\
\hline & $\begin{array}{l}\text { Not } \\
\text { designed for }\end{array}$ & $\begin{array}{l}\text { - Detailed information related to the } \\
\text { rationale for recommendations. } \\
\text { - Finding references to the } \\
\text { research studies that vaccine } \\
\text { recommendations are based on. } \\
\text { - Epidemiologic reviews of vaccine } \\
\text { preventable diseases. }\end{array}$ \\
\hline & Timelines & $\begin{array}{l}\text { - Each chapter is reviewed } \\
\text { - every four years, OR } \\
\text { - When a new statement is written. }\end{array}$ \\
\hline & $\begin{array}{l}\text { Where to } \\
\text { find it }\end{array}$ & $\begin{array}{l}\text { Canadian Immunization Guide } \\
\text { (http://www.phac-aspc.gc.ca/publicat/ } \\
\text { cig-gci/index-eng.php) }\end{array}$ \\
\hline \multirow{4}{*}{$\begin{array}{l}\mathrm{NACl} \text { summaries } \\
\text { in the Canada } \\
\text { Communicable } \\
\text { Disease Report } \\
\text { (CCDR) }\end{array}$} & Designed for & $\begin{array}{l}\text { - Finding out about new } \mathrm{NACl} \\
\text { recommendations. }\end{array}$ \\
\hline & $\begin{array}{l}\text { Not } \\
\text { designed for }\end{array}$ & $\begin{array}{l}\text { - Knowing all the evidence base and } \\
\text { rationale for the recommendations. }\end{array}$ \\
\hline & Timelines & $\begin{array}{l}\text { - Available shortly after a new } \mathrm{NACl} \\
\text { statement is published. }\end{array}$ \\
\hline & $\begin{array}{l}\text { Where to } \\
\text { find them }\end{array}$ & $\begin{array}{l}\text { Canadian Communicable Disease } \\
\text { Report (CCDR) } \\
\text { (http://www.phac-aspc.gc.ca/ } \\
\text { publicat/ccdr-rmtc/) }\end{array}$ \\
\hline
\end{tabular}

\section{Conclusion}

New vaccines, research and immunization strategies are being developed all the time to prevent and minimize the effects of infectious diseases, as well as to optimize safety and efficiency of vaccine administration. $\mathrm{NACl}$ continues to develop immunization information and guidance products to meet the needs of a diverse readership. Understanding the purpose and content of each product will help public health professionals and clinicians choose the most appropriate product.

Those who are interested can receive ongoing updates of $\mathrm{NACl}$ related products by joining the NACl list serve (13). Any questions or comments related to $\mathrm{NACl}$ statements, evidence-based reviews and the Canadian Immunization Guide, can be sent through the Contact Us feature on the PHAC website (14).

\section{Acknowledgements}

The authors would like to acknowledge the hard work of all $\mathrm{NACl}$ members past and present and their commitment to immunization guidance for Canada.

\section{Conflict of interest}

None.

\section{Funding}

$\mathrm{NACl}$ is financially supported by the Public Health Agency of Canada.

\section{References}

1. Public Health Agency of Canada. National Advisory Committee on Immunization [Internet]. Ottawa ON: 2016 [updated $2016 \mathrm{Jul}$ 7, cited 2016 July 26]. Available from: http://www.phac-aspc.gc.ca/naci-ccni/.

2. Langley JM. Evidence-based recommendations for immunization: Methods of the National Advisory Committee on Immunization. Can Comm Dis Rep [Internet]. 2009;35(ACS-1):1-10. Available from: http://www.phac-aspc. gc.ca/publicat/ccdr-rmtc/09vol35/acs-1/index-eng.php.

3. Advisory Committee Statement (ACS) National Advisory Committee on Immunization (NACl). Update on the recommended use of Hepatitis A vaccine [Internet]. Ottawa: PHAC; 2016 [cited 2016 Oct 24]. Available from: http://www. healthycanadians.gc.ca/publications/healthy-living-vie-saine/ hepatitis-a-vaccine-update-recommended-use-2016-mise-ajour-recommandations-hepatite-a-vaccin/alt/pub-eng.pdf.

4. Advisory Committee Statement (ACS) National Advisory Committee on Immunization (NACI). Update on MeaslesMumps-Rubella-Varicella Vaccine and Febrile Seizures 
[Internet]. Ottawa: PHAC; 2016 [cited 2016 Oct24]. Available from: http://healthycanadians.gc.ca/publications/healthyliving-vie-saine/vaccine-measles-mumps-rubella-varicellaseizures-2016-vaccin-rougeole-rubeole-oreillons-varicelleconvulsions/alt/pub1-eng.pdf.

5. Ismail SJ, Langley JM, Harris TM, Warshawsky BF, Desai S, Farhang Mehr M. Canada's National Advisory Committee on Immunization (NACl): Evidence-based decision-making on vaccines and immunization. Vaccine. 2010;28(S):A58-63.

6. Public Health Agency of Canada. A review of the literature of high dose seasonal influenza vaccine for adults 65 years and older [Internet]. Ottawa: PHAC; 2016 [updated 2016 Apr 11, cited 2016 Oct 11]. Available from: http://www. phac-aspc.gc.ca/naci-ccni/influenza-vaccine-65-plus-vaccincontre-la-grippe-65-plus-eng.php.

7. Advisory Committee Statement (ACS) National Advisory Committee on Immunization (NACl). Canadian immunization guide chapter on influenza and statement on seasonal influenza vaccine for 2016-2017 [Internet]. Ottawa: PHAC; 2016 [cited 2016 Oct 11]. Available at: http://www.phacaspc.gc.ca/naci-ccni/flu-2016-grippe-eng.php\#v.

8. National Advisory Committee on Immunization (NACl). Canadian immunization guide introduction [Internet]. Ottawa: PHAC; 2014 [cited 2016 Jul 26]. Available from: http://www.phac-aspc.gc.ca/publicat/cig-gci/introductioneng.php.

9. National Advisory Committee on Immunization (NACl). Canadian immunization guide tables of updates [Internet]. Ottawa: PHAC; 2016 [cited 2016 July 26]. Available from: http://www.phac-aspc.gc.ca/publicat/cig-gci/errata-eng.php.
10. Jensen C, Lerch R on behalf of the National Advisory Committee on Immunization. Updates to the Canadian Immunization Guide: April 2015 to October 2016. Can Comm Dis Rep. 2016;(42)12:256-9. Available from: http:// www.phac-aspc.gc.ca/publicat/ccdr-rmtc/16vol42/drrm42-12/ar-04-eng.php.

11. National Advisory Committee on Immunization (NACl). Canadian immunization guide. Part 1: Key immunization information [Internet]. Ottawa: PHAC; 2016 [cited 2016 July 26]. Available from: http://healthycanadians. gc.ca/publications/healthy-living-vie-saine/4-canadianimmunization-guide-canadien-immunisation/index-eng. php?page=9.

12. Quach C, Baclic $O$ on behalf of the National Advisory Committee on Immunization (NACl). Summary of the $\mathrm{NACl}$ interim recommendations on the use of pneumococcal vaccines in immunocompetent adults 65 years of age and older. Can Comm Dis Rep. 2016;42(12): 260-2. Available from: http://www.phac-aspc.gc.ca/publicat/ccdrrmtc/16vol42/dr-rm42-12/ar-05-eng.php.

13. Government of Canada [Internet]. Canadian Immunization Guide update - Mailing list. [updated 2014 May 13; cited 2016 Oct 24]. Available from: http://healthycanadians. gc.ca/healthy-living-vie-saine/immunization-immunisation/ canadian-immunization-guide-canadien-immunisation/emailsubscription-abonnement-courriel-eng.php.

14. Public Health Agency of Canada [Internet]. Contact us. [updated 2016 Aug 11; cited 2016 Oct 24]. Available from: http://www.phac-aspc.gc.ca/contac-eng.php.

\section{THE FACTS ON VACCINES FOR ADULTS AND TEENS}

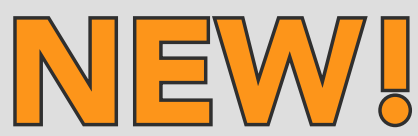

FREE INFO GUIDES AVAILABLE

+ Free to order online

+ Free shipping Available in any quantity Available in both official languages

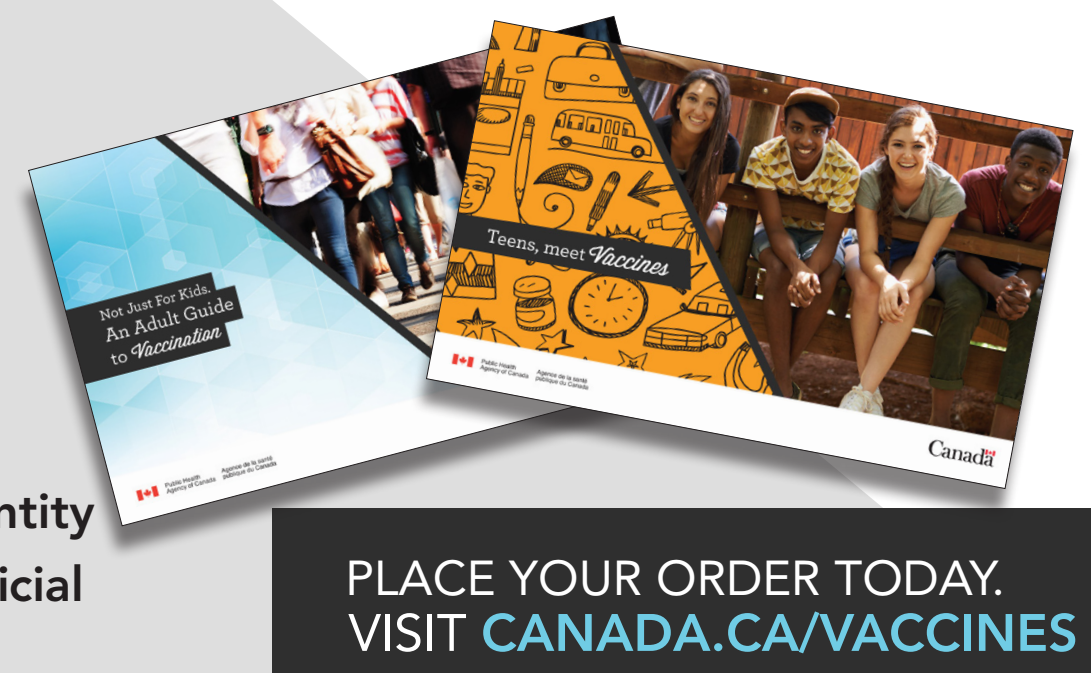

